\title{
The Relationship Between Transformational Leadership, Leader Effectiveness, and Turnover Intentions: Do Subordinate Gender Differences Exist?
}

\author{
Janelle E. Wells \\ Florida State University \\ Jon Welty Peachey \\ University of Illinois
}

Nefertiti Walker

University of Massachusetts-Amherst

\begin{abstract}
The aim of this study was to examine gender differences among subordinates in the strength of relationships between transformational leadership, leader effectiveness, and voluntary organizational turnover intentions. The authors drew from various theoretical bases, including transformational leadership theory, social role theory, and role congruity theory, to undergird the research. National Collegiate Athletic Association (NCAA) Division I male and female assistant coaches of women's basketball, softball, and volleyball teams $(N=294)$ responded to the Multifactor Leadership Questionnaire (MLQ) and turnover intention questionnaire. Structural equation modeling $(S E M)$ revealed a noteworthy gender difference in the strength of relationship between leader effectiveness and voluntary organizational turnover intentions. Contributions and implications are discussed.
\end{abstract}

Keywords: leadership, effectiveness, intercollegiate athletics, turnover

Voluntary turnover represents the process of an individual making the decision to stay or leave an organization (McPherson, 1976). It can be costly (Abbasi \& Hollman, 2000), dysfunctional, and detrimental (Mobley, 1982) to organizations in all industry sectors, sport included. In addition, as more people voluntarily leave their place of employment, the performance of that entity is likely to decline

\footnotetext{
Wells is with the Dept. of Sport Management, Florida State University, Tallahassee, FL. Welty Peachey is with the Dept. of Recreation, Sport and Tourism, University of Illinois, Champaign, IL. Walker is with the Dept. of Sport Management, University of Massachusetts-Amherst, Amherst, MA. Address author correspondence to Janelle Wells at jewells@fsu.edu.
} 
(Abassi \& Hollman, 2000; Hill, 2009; Salomo \& Teichmann, 2000; Shaw, Gupta, \& Delery, 2005; White, Persad, \& Gee, 2007).

Given its importance to organizational outcomes, scholars have investigated ways in which voluntary organizational turnover can be mitigated. One avenue for reducing turnover could be leadership. The limited literature suggests that effective leaders are a key factor in reducing voluntary turnover (Bycio, Hackett, \& Allen, 1995; Cicero, Pierro, \& van Knippenberg, 2010). In a broader sense, effective leadership is a central concern for organizations, scholars, and practitioners (Kozlowski \& Ilgen, 2006). For the past 50 years, a vast body of literature has focused on the evolution of leadership paradigms (Higgs, 2003). Recently, transformational and transactional leadership behaviors have been the focus of managerial literature (Judge \& Piccolo, 2004; Yukl, 2006) and have garnered attention among sport scholars as well (Burton \& Peachey, 2009; Choi, Sagas, Park, \& Cunningham, 2007; Doherty \& Danylchuk, 1996; Wells \& Welty Peachey, 2011; Welty Peachey \& Burton, 2011, 2012).

Within the sport context, scholars have investigated the relationship between leadership behaviors and organizational outcomes (Burton \& Peachey, 2009; Choi et al., 2007; Doherty \& Danylchuk, 1996; Wells \& Welty Peachey, 2011; Welty Peachey \& Burton, 2011, 2012), as well as antecedents and consequences of turnover intentions (Cunningham \& Sagas, 2003; Cunningham \& Sagas, 2004; Hill, 2009; Sagas \& Ashley, 2001). Results from this work suggest perceived leader effectiveness is impacted by leader behaviors (e.g., Welty Peachey \& Burton, 2011, 2012), and perceived leader effectiveness can in turn influence voluntary turnover intentions (Bycio et al., 1995; Cicero et al., 2010). However, the majority of research on leadership styles have focused on the gender of the manager alone (Grissom, Nicholson-Crotty, \& Keiser, 2012), but differences between male and female subordinates in the strength of these relationships has gone otherwise unexplored. It may be that transformational leadership, for instance, influences perceptions of leader effectiveness for one gender more than the other, or that male and female subordinates differ in how leader effectiveness influences their turnover intentions.

These compelling questions are important to understand regardless of cultural context, as mitigating voluntary turnover is a central concern of many sport organizations worldwide (Wells \& Welty Peachey, 2011). To gain insight into gender differences with regards to the relationship between leadership and turnover intentions in sport, we positioned this study within the National Collegiate Athletic Association (NCAA) Division I context in the U.S. The aim of this study was to examine whether there was a gender difference among subordinates in the strength of the relationships between transformational leadership, leader effectiveness, and voluntary organizational turnover intentions. To explore this topic, we drew from various theoretical perspectives, including transformational leadership theory, social role theory, and role congruity theory, to suggest that (a) transformational leadership will be positively related to perceived leader effectiveness and (b) the relationship between leader effectiveness and turnover intentions will be contingent upon the gender of the subordinates.

\section{Transformational Leadership}

Initially conceptualized by Burns (1978) and later tailored by Bass (1985, 1990), transactional and transformational leadership has gained traction among sport and management scholars (Burton \& Peachey, 2009; Doherty, 1997; Duehr \& Bono, 
2006; Eagly, Johannesen-Schmidt, \& van Engen, 2003; Judge \& Piccolo, 2004; Wells \& Welty Peachey, 2011; Welty Peachey \& Burton, 2011, 2012). Transactional leadership is aligned with more classical views of leadership, whereas transformational leadership is considered a new approach to leadership theory (Doherty, 1997), where leaders recognize the higher order needs of subordinates (Burns, 1978).

Transformational leaders transcend the exchange-based process of transactional leaders by engaging followers' values (Bass, 1985). Transformational leaders have been known to use optimism and commitment to inspire and motivate their followers (Duehr \& Bono, 2006). According to Bass $(1985,1998)$, transformational leaders tend to the needs of their followers, connect performance goals to employee values, and challenge traditional practices. Thus, transformational leadership is the process of "influencing major change in the attitudes and assumptions of organization members and building commitment for the organization's mission or objectives" (Yukl, 1989, p. 204). Transformational leaders are inherently social and modify their behaviors according to the environment or dynamic interactions with followers (Bass, 1985). Consequently, they influence followers by engaging higher-order needs, encouraging goals of the team, and focusing on the values of the task by earning respect, trust, and admiration from followers (Bass, 1985). Four distinct yet interrelated types of behavior define transformational leadership: idealized influence or charisma-providing vision and instilling pride, trust, and respect; individual consideration-giving personal attention and treating each employee individually; inspirational motivation-communicating high expectations and using symbols to focus efforts; and intellectual stimulation-promoting intelligence and careful problem solving (Bass, 1985). Through these four behaviors, transformational leaders inspire and encourage followers to use novel perspectives and solutions to problem solve.

In general, transformational leadership is associated with more positive organizational outcomes than is transactional leadership. For example, Judge and Piccolo's (2004) meta-analysis revealed positive effects of transformational leadership behavior on the outcomes of employee attitude, employee motivation, performance, and leader effectiveness. Since this meta-analysis, other business management research has associated transformational leadership with higher work team effectiveness, leader effectiveness, and performance (Polychroniou, 2009; Wang \& Huang, 2009), as well as with reducing voluntary turnover intentions (Tse \& Lam, 2008).

Within the U.S. intercollegiate sport context, transformational leadership is associated with perceived extra effort among NCAA Division I, II, and III athletic directors (Burton \& Peachey, 2009; Welty Peachey \& Burton, 2011, 2012). Transformational leadership of the athletic director in the U.S. and Canadian intercollegiate contexts also has positive effects on affective organizational commitment and perceived leader effectiveness (Choi et al., 2007; Doherty \& Danylchuk, 1996, Kent \& Chelladurai, 2001). Transformational leadership is related to Canadian intercollegiate athletes' holistic development and team success (Vallee \& Bloom, 2005); perceptions of coaches' effectiveness and extra effort among martial arts athletes (Rowold, 2006); task and social cohesion in frisbee club athletes (Callow, Smith, Hardy, Arthur, \& Hardy, 2008).

Although the aforementioned research has been instrumental in extending scholarship on leadership, and some sport management work has examined the influence of leader gender on various outcome variables (Burton \& Peachey, 2009; 
Welty Peachey \& Burton, 2011, 2012; Wells \& Welty Peachey, 2011), what appears to be missing is a thorough examination of the differences between female and male subordinates as related to the relationships between transformational leadership, leader effectiveness, and voluntary turnover intentions. Acknowledging this need, the current study addresses this gap in our empirical and conceptual understanding.

\section{Social Role Theory and Role Congruity Theory}

To examine whether there is a gender difference among subordinates in the strength of the relationships between transformational leadership, leader effectiveness, and voluntary organizational turnover intentions, we drew from social role theory and role congruity theory (Eagly, 2007; Eagly \& Karau, 2002). Social role theory suggests that there are qualities and behavioral tendencies believed to be desirable for each gender, as well as expectations as to which roles males and females should occupy (Eagly \& Karau, 2002). Women's leadership skills have been described through communal characteristics such as affectionate, helpful, kind, sympathetic, interpersonally sensitive, nurturing, and gentle (Eagly, 1987; Eagly, Wood, \& Diekman, 2000). In contrast, men have been described by agentic characteristics such as aggressive, dominant, forceful, self-confident, and self-sufficient (Eagly, 1987; Eagly et al., 2000). Thus, prescriptive gender role stereotypes suggest that females should exhibit more communal characteristics and roles, while males may have more agentic qualities (Eagly \& Karau, 2002).

Role Congruity Theory Emerged From Social Role Theory and Holds:

Female gender role and leadership roles leads to 2 forms of prejudice: (a) perceiving women less favorably than men as potential occupants of leadership roles and (b) evaluating behavior that fulfills the prescriptions of a leader role less favorably when it is enacted by a woman (Eagly \& Karau, 2002, p. 573).

As such, transformational leaders have been noted to be more congruent with stereotypical feminine gender roles, while transactional leaders have been associated with stereotypical masculine gender roles (Powell, Butterfield, \& Bartol, 2008). Specifically in the Canadian intercollegiate context, female leaders have been recognized as demonstrating more transformational leadership behaviors than males (Doherty, 1997). Moreover, in the U.S. business setting, male leaders have been identified as demonstrating more transactional leadership behaviors (Eagly \& Carli, 2003). Eagly, Johannesen-Schmidt, and van Engen's (2003) meta-analysis on gender differences in leadership behaviors revealed females were rated higher than their male counterparts on the majority of transformational leadership dimensions.

Leader effectiveness is realized through the manifestation of both feminine and masculine traits (Duehr \& Bono, 2006; Eagly, 2007). While researchers female and male subordinates rate transformational leaders more effective than transactional leaders (Eagly \& Carli, 2003; Powell et al., 2008), overall, female leaders are perceived as more effective when using communal characteristics and acting as transformational leaders (Duehr \& Bono, 2006; Eagly \& Carli, 2003). Females might also have a leadership advantage over males as a result of demonstrating more transformational leadership behaviors, which are positively associated with organizational effectiveness (Eagly, 2007; Eagly \& Carli, 2003). 
Given that females exhibit more transformational leadership behaviors, it stands to reason that subordinates will respond better to transformational leadership displayed by female leaders, as these behaviors will resonate with their socially prescribed roles of being communal (Eagly \& Karau, 2002). Furthermore, given male leaders exhibit more transactional leadership behaviors, but were not perceived as more effective due to the transactional leadership style (Burton \& Welty Peachey, 2009; Powell et al., 2008), a subordinate would value relationship-building and the nurturing and care that a transformational leader provides, satisfying communal orientation and social expectations, rather than transactional leadership. If this is the case, then it seems as though the relationship between transformational leadership and perceived leader effectiveness may mitigate the effect of role congruity theory. Thus, we posit the following:

\section{Hypothesis 1:}

Transformational leadership will be positively related to perceptions of leader effectiveness among all subordinates, regardless of gender.

It must be noted that we focus on subordinate gender in this study, rather than leader gender. As mentioned previously, females exhibit more transformational leadership behaviors, and males more transactional leadership behaviors (Doherty, 1997; Eagly \& Carli, 2003). Further, gender of the leader does not influence outcomes such as extra effort and perceived leader effectiveness (Burton \& Peachey, 2009; Welty Peachey \& Burton, 2011, 2012). Thus, in the current study, we single out subordinate gender to contribute to the literature over and above these previous studies.

\section{Organizational Turnover}

With an increasing knowledge-based economy, organizations that retain human resources may be at an advantage over those that cannot (Felps et al., 2009). Indeed, numerous studies have shown the negative effects of turnover on performance, financial costs, morale, and efficiencies (Abbasi \& Hollman, 2000; Shaw et al., 2005; Watrous, Huffman, \& Pritchard, 2006). Furthermore, coaching successions in collegiate basketball in the U.S. (Fizel \& D'Itri, 1996), midseason coaching successions in the National Hockey League in the U.S. (White et al., 2007), outof-season coaching successions in the English Premier League (Audas, Dobson, \& Goddard, 2002) as well as managerial successions in the German Premier Soccer League (Salomo \& Teichmann, 2000) all have negative effects on organizational performance.

Whether this turnover has been categorized as involuntary or voluntary, or as dysfunctional or functional (Watrous et al., 2006), damaging effects on organizations have been revealed. The most detrimental turnover to an organization is voluntary turnover (Mobley, 1982). Since voluntary organizational turnover represents a well-performing employee vacating her or his position by choice, not only does the employee depart the organization, but so does the associated knowledge and experience, which can have deleterious effects for the organization.

Rather than examine turnover, this study investigated turnover intentions. When an employee intends to leave an organization, she or he goes through a cognitive 
process of thinking to quit, planning to leave the job, and desiring to leave the job (Mobley, Griffeth, Hand, \& Meglino, 1979). Since voluntary turnover intentions have been regarded as a direct proxy of actual turnover (Lee \& Mowday, 1987; Mobley, 1982; Mowday, Koberg, \& McArthur, 1984; Rosser \& Townsend, 2006), there are advantages to studying turnover intentions rather than actual turnover. Oftentimes it is difficult to gain access to and obtain accurate information about former employees; thereby highlighting the importance of querying employees before their departure (Firth, Mellor, Moore, \& Loquet, 2004). In addition, based upon feedback from research, organizations still have a chance to institute changes that may influence their employees' turnover intentions (Dalessio, Silverman, \& Schuck, 1986).

A number of predictors, including the presence of effective leaders (Bycio et al., 1995; Cicero et al., 2010), job satisfaction (Griffith, 2004), and affective occupational commitment (Cunningham, Sagas, \& Ashley, 2001) are negatively related to turnover intentions. Conversely, negative work experiences (Cunningham \& Sagas, 2003), as well as ethnic and tenure diversity (Cunningham \& Sagas, 2004), have the potential to positively influenced turnover intentions.

The findings regarding turnover differences between women and men are mixed. Whether voluntary or involuntary, Sicherman (1996) found women to have higher turnover rates than men. While turnover research has traditionally suggested that women, on average, have higher turnover rates when compared with men (Lyness \& Judiesch, 2001; Son, Joshi, \& Roh, 2012; Stroh, Brett, \& Reilly, 1996; Weisberg \& Kirschenbaum, 1993), more recent research in the public sector (Moynihan \& Landuyt, 2008) and at the management level (Lyness \& Judiesch, 2001) points to an opposite trends.

While the leadership style, social role theory, and role congruity theory literatures (Eagly, 2007; Eagly \& Johnson, 1990; Eagly \& Karau, 2002) described earlier suggest supervisor and subordinate gender impact the work lives of employees and turnover, the literature is complex (Grissom et al., 2012). Although both male and female subordinates value stereotypical feminine leadership styles (i.e., transformational; Eagly \& Johnson, 1990; Riger, 1993), there is also some evidence to suggest subordinates expect leaders to be males and use more agentic characteristics (Eagly, 1987; Eagly et al., 2000). As a result, followers will seek to align these social role stereotypes with masculine qualities, which could cause subordinates of both genders to systematically be less willing to work for a leader with more masculine qualities (Grissom et al., 2012; Heilman, Block, Martell, \& Simon, 1989). Nonetheless, most scholars argue that women and men are less likely to leave an organization when their supervisor adopts a feminine leadership style (Grissom et al., 2012). According to Grissom et al. (2012), stereotypical leadership beliefs remain consistent among men, but are no longer held by women. Consequently, the varying aforementioned literature on voluntary organizational turnover intentions and gender led us to the following hypothesis:

\section{Hypothesis 2:}

A significant subordinate gender difference will exist in the relationship between perceptions of leader effectiveness and voluntary organizational turnover intentions. 
The relationships between the hypotheses are depicted in Figure 1.

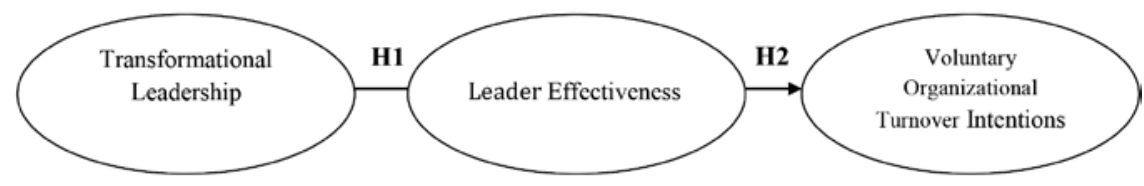

Figure 1 - Hypothesized Path

\section{Method}

\section{Participants}

We collected data from 294 NCAA Division I basketball, softball, and volleyball assistant coaches. Most of the participants were female $(n=193,65.6 \%)$, while the rest identified as male $(n=101,34.5 \%)$. On average, the organizational tenure of assistant coaches was four years $(S D=3.19)$ and the age of assistant coaches was 33 years $(S D=8.09)$. The majority of respondents identified themselves as White $(n=217,73.8 \%)$ or African American $(n=41,13.9 \%)$.

\section{Measures}

The Multifactor Leadership Questionnaire (MLQ_Form 5×, Bass \& Avolio, 2000) was used to evaluate head coach's leadership behavior and perceived leader effectiveness on a five-point Likert-type scale ranging from 0 (not at all) to 4 (frequently, if not always). Transformational leadership was categorized into the following groups: idealized influence-attributes, inspirational motivation, idealized influence-behavior, intellectual stimulation, and individualized consideration. For example, the statement "Articulates a compelling vision of the future" was a measure of the participants' perception of their head coach's inspirational motivation. Due to the highly correlated MLQ transformational subscale scores, an average transformational leadership score was calculated. Participants also rated three perceived leader effectiveness (e.g., is effective in meeting subordinates' job-related needs) items, which had an acceptable reliability estimate $(\alpha=.86)$.

In addition, similar to previous turnover intention studies in sport (Cunningham, 2006; Cunningham, 2007; Wells \& Welty Peachey, 2011), a three-item scale was used to measure voluntary organizational turnover intentions. An example item was "I will try to leave this coaching staff within the next year." The voluntary organizational turnover measure had an acceptable reliability estimate $(\alpha=.96)$.

\section{Procedures}

Since $57.1 \%$ of all women's team paid assistant coaches in the NCAA are female (Acosta \& Carpenter, 2012), we narrowed our study to focus on teams with the most equally distributed gender of head and assistant coaches, which were NCAA 
Division I women's basketball (65.2\% women head coaches), softball $(60 \%$ women head coaches), and volleyball ( $45.8 \%$ women head coaches) teams. Theoretically, this provided the best opportunity to assess gender differences among the strength of the variables. To access NCAA Division I women's basketball, softball, and volleyball collegiate assistant coaches, we collected e-mail addresses from the current websites of NCAA Division I institutions. Once Institutional Review Board (IRB) approval was granted, we sent an initial e-mail invitation to the NCAA Division I assistant coaches to inform them about an upcoming survey and to recruit them to participate. Two days following the invitation the online survey was released. Then once a week over a two-week period a reminder e-mail was delivered to nonrespondents through the web-based survey tool, Qualtrics. While participants remained anonymous, Qualitrics does have the ability to track respondents and nonrespondents through the survey link provided in the e-mail invitation. A total of 1,268 NCAA Division I basketball, softball, and volleyball female and male assistant coaches were recruited to participate in this study. Of the 1,268 participants recruited, $294(N=294)$ responded for a response rate of $23.2 \%$.

To compare early and late responders analysis of variance (ANOVA) was administered. No significant differences were found between the respondents.

Given the low response rate, we took two steps to consider whether nonresponse bias was a problem. First, we compared early and late responses, as late responders are likely to have similar characteristics as nonresponders. With this reasoning, differences between early and late responders would suggest nonresponse bias is an issue (Dooley \& Lindner, 2003). An analysis of variance indicated this was not the case. We also compared the demographics of our sample to those in other reports. The representation of women $(65.6 \%)$ and men $(34.5 \%)$ in our sample is representative of the gender distribution of Division I assistant coaches of women's teams (Acosta \& Carpenter, 2012). In addition, the racial distribution of our sample closely mirrored those reported in previous research (Cunningham \& Sagas, 2003; Sagas, Cunningham, \& Pastore, 2006). Collectively, these data suggest that while our response rate was low, questions related to the representativeness of the sample are not a primary concern.

\section{Results}

Data analysis was conducted using SPSS 20.0 as well as Muthen \& Muthen's Mplus Version 6. To investigate the hypothesized relationships between transformational leadership, leader effectiveness, and voluntary organizational turnover intentions, multigroup structural equation modeling (SEM) was employed. First, a baseline model without any constraints on the groups was performed. Then, equality constraints were conducted across the two samples and chi-square difference tests assessed the differences on the parameters of the models (Anderson \& Gerbing, 1988; Byrne, 2012).

Descriptive statistics (see Table 1) were computed for each of the variables, and Mplus was used to examine differences by gender of the participant. Before analyzing the data, preliminary analyses tested for normality, homoscedasticity, and linearity to make certain violations did not occur and no violations were found. 
Table 1 Means and Standard Deviations (SD) of the Variables by Participant Gender

\begin{tabular}{lcc}
\hline & $\begin{array}{c}\text { Participant } \\
\text { Gender }\end{array}$ & Means (SD) \\
\hline 1. Transformational Leadership & Female & $2.63(0.81)$ \\
& Male & $2.62(0.91)$ \\
2. Leadership Effectiveness & Female & $2.63(0.97)$ \\
3. Voluntary Organizational Turnover Intentions & Male & $2.66(0.73)$ \\
& Female & $1.11(1.28)$ \\
& Male & $1.43(1.45)$ \\
\hline
\end{tabular}

Note. A Likert-type scale ranging from $4=$ frequently, if not always to $0=$ not at all was used to measure all variables.

\section{Model Fit Indices}

To indicate a good model, Hu and Bentler (1998) suggest cut-off values less than 0.06 for Root Mean Square Error of Approximation (RMSEA), and Comparative Fit Index (CFI) greater than 0.95. First, the measurement model performed well: $\chi^{2} / d f=2.16$; RMSEA $=0.05$; Standardized Root Mean Square Residual $(\mathrm{SRMR})=0.06 ; \mathrm{CFI}=0.95$, and Tucker Lewis Index $(\mathrm{TLI})=0.94$. Each of the estimated loadings was significant. In addition, the baseline (without any constraints among the groups) met good model fit values: $\chi^{2} / d f=1.66$; RMSEA $=$ 0.06; $\mathrm{SRMR}=0.07$; $\mathrm{CFI}=0.94$; and $\mathrm{TLI}=0.93$. Next, a structural invariance model (Byrne, 2012) was conducted. This constraint model met the marginal model fit values: $\chi^{2} / d f=1.26$; RMSEA $=0.06$; $\mathrm{SRMR}=0.07$; CFI $=0.94$; and $\mathrm{TLI}=0.94$.

\section{Model}

Hypothesis 1, which stated transformational leadership will be positively related to perceptions of leader effectiveness among all subordinates, regardless of gender (see Figure 2; Males: $\beta=0.77, p<.05$; Females: $\beta=0.78, p<.05$ ), did not reveal a statistically significant $\chi^{2}$ difference test $\left(\Delta \operatorname{MLM} \chi^{2}(145)=171.59, p>.05\right)$. Thus, this hypothesis was supported.

In support of Hypothesis 2, which stated a significant subordinate gender difference will exist in the relationship between perceptions of leader effectiveness and voluntary organizational turnover intentions, male subordinates perceived leader effectiveness to be more negatively related to voluntary organizational turnover intentions than female subordinates (see Figure 2; Males: $\beta=-0.57, p<.05$; Females: $\beta=-0.47, p<.05$ ), and the $c^{2}$ difference test revealed significant differences between males and females ( $\Delta$ MLM $\chi^{2}$ $(145)=177.59, p<.05)$. 


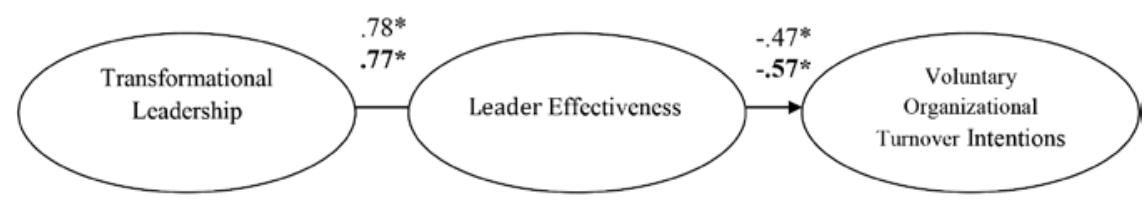

Figure 2 - Results of gender differences between transformational leadership, leader effectiveness, and voluntary organizational turnover intentions. Note. ${ }^{*}$ Significant at the 0.05 level. Male assistant coach results are bold and listed second.

\section{Discussion}

The aim of this study was to examine if there were gender differences in the strength of the relationships between transformational leadership, leader effectiveness, and voluntary organizational turnover intentions. These are areas not examined in previous research from the perspective of subordinate gender differences. Our first hypothesis, which stated that transformational leadership will be more positively related to perceptions of leader effectiveness among all subordinates, regardless of gender, was supported. This finding is important and extends previous leader effectiveness literature (Bass, 1997; Bycio et al., 1995) by demonstrating that transformational leadership is positively associated with perceptions of leader effectiveness, irrespective of gender.

Given these findings, we submit it is possible that transformational leadership may help mitigate the effects role congruity theory (Eagly, 2007; Eagly \& Karau, 2002). Perhaps the highly competitive environment of NCAA Division I athletics requires both communal and agentic characteristics to achieve organizational objectives and field competitive teams. The unique nature of sport might also make these effects more salient. Sport teams require goal- and task-orientation and coordination in the pursuit of winning and common objectives, just like in other business environments, but what could be different is that the sport team context requires a high degree of communal and relational foci as well, to get teammates to work together effectively. This relational aspect undergirding interdependent actions and behaviors of teammates could be more pronounced in the sport setting than in other business environments, due to the amount and nature of coordination and interdependence that is required to achieve objectives. Both female and male subordinates in intercollegiate sport, and other sport contexts, may recognize that the transformational qualities of a leader are necessary to achieve performance success. As such, both female and male subordinates could equally perceive a transformational leader to be effective.

Consistent with our expectations, we observed that gender moderated the relationship between perceptions of leader effectiveness and voluntary organizational turnover intentions. This finding reinforces previous studies that suggest perceived leader effectiveness influences voluntary turnover intentions (Bycio et al., 1995; Cicero et al., 2010). Importantly though, our work extends the understanding of how gender is related to perceptions of leader effectiveness and voluntary 
organizational turnover intentions. Although NCAA Division I athletics is a highly competitive sport environment where both female and male subordinates value the ability of a leader to achieve organizational objectives and field competitive teams, as we argue, and following social role and role congruity theories (Eagly, 1987; Eagly \& Karau, 2002; Eagly et al., 2000), female subordinates may use a holistic approach inclusive of relationships and communal aspects of the organization with regards to their turnover decisions. Male subordinates, on the other hand, could equate socially prescribed roles of aggressive and forceful decision-making with leader effectiveness, and if a leader is not perceived as being effective, the male subordinate may wish to leave to align with a leader perceived to have a better chance of obtaining organizational outcomes, or in this case, winning. However, it is important to note that male subordinates also valued transformational leadership and rated transformational leaders as effective. This is encouraging, as it shows that despite an agentic orientation for males, transformational leadership is also valued, although perhaps not enough to prevent turnover if the leader is not perceived as being effective.

\section{Implications}

Theoretically, we have demonstrated that a gender difference exists in the strength of the relationship between perceived leader effectiveness and voluntary turnover intentions. This is an important contribution to the leadership and turnover literatures, as the differences between female and male subordinates with regards to these variables have not been previously examined. Thus, to examine prevailing gender structures and better understand leadership in sport settings (Shaw \& Frisby, 2006), this model of leadership and turnover in sport accounted for potential gender differences, not only of leaders, but also of followers. Given that transformational leadership is perceived to be more effective in achieving organizational outcomes in this context, continued work is needed to understand why women are excluded from leadership positions, especially in intercollegiate athletics, if they do indeed exhibit more transformational leadership behaviors (Eagly, 2007).

From a practical standpoint, athletic directors and hiring managers should consider hiring qualified head coaches and other sport managers with both feminine and masculine traits to successfully manage diverse staffs (Duehr \& Bono, 2006; Eagly, 2007), and who demonstrate transformational leadership behaviors to increase leader effectiveness, as well as mitigate turnover intentions. Specifically in a team or interdependent environment, hiring managers should identify and recruit leaders with balanced agentic and communal qualities to create collaborative, competitive, and successful teams. Furthermore, coaches and managers should foster healthy working conditions and monitor the effectiveness of organizational and team leadership to reduce voluntary turnover.

\section{Limitations and Future Research}

Although the results of this research add to the literature there are limitations to our study. To begin, there are other explanatory variables which may contribute to the voluntary organizational turnover intentions of assistant coaches that we did not assess, such as pursuing a head coaching position or family-work conflict. However, we did follow other sport scholars (Cunningham \& Sagas, 2003; Cunningham \& 
Sagas, 2004; Hill, 2009; Sagas \& Ashley, 2001) who examined voluntary turnover intentions in sport, but further research should attempt to tease out additional explanatory factors. Further, the sports that we chose were all women's team sports, where the proportion of women and men in leadership positions are relatively comparable (see Acosta \& Carpenter, 2012). Lastly, the timing of data collection may have influenced assistant coaches' perceptions of viable job opportunities. As Wells and Welty Peachey (2011) noted, the timing variance of seasons (i.e., basketball in winter, softball in the spring, and volleyball in the fall) impacts perspectives of feasible job opportunities.

While we have extended the literature and created a comparison, there is still a need to expand the literature by conducting similar research on gender differences in the strength of the relationships between leadership behaviors, leader effectiveness, and voluntary organizational turnover intentions in other sport settings, such as professional, youth, community, and nonprofit sport. Perhaps findings will differ based upon sport context. In particular, less competitive sport environments could yield different results than the highly competitive Division I context of our study. In addition to pursuit of a head coaching position or family-work conflict, other explanatory variables such as leader member exchange and organizational commitment (Tse \& Lam, 2008) are not included in our path, but should be examined in future research. Finally, there may be gender differences in the strength of the relationships between other leadership behaviors (e.g., transactional, servant, or authentic leadership) and outcome variables that would be worthwhile investigating, such as trust in the leader, satisfaction, withdrawal behaviors (Eisenberger, Armeli, Rexwinkel, Lynch, \& Rhoades, 2001), job search behaviors (Bretz, Boudreau, \& Judge, 1994), as well as organizational commitment and citizenship behaviors (Meyer, Stanley, Herscovitch, \& Topolnytsky, 2002; Organ \& Ryan, 1995).

\section{Conclusion}

As noted, the aim of this study was to examine whether there was a gender difference among subordinates in the strength of the relationships between transformational leadership, perceived leader effectiveness, and voluntary organizational turnover intentions. This study built upon previous literature by comparing female and male antecedents to voluntary organizational turnover intentions of assistant coaches in NCAA collegiate sports. An important theoretical contribution was the comparison models, which revealed male assistant coaches, more than their female counterparts, rated leader effectiveness to be more negatively related to voluntary organizational turnover intentions.

\section{References}

Abbasi, S.M., \& Hollman, K.W. (2000). Turnover: The real bottom line. Public Personnel Management, 29, 333-342.

Acosta, R.V., \& Carpenter, L.J. (2012). Women in intercollegiate sport: A longitudinal, national study thirty five year update (1977-2012). Retrieved March 1, 2012 from http://www.acostacarpenter.org/.

Anderson, J.C., \& Gerbing, D.W. (1988). Structural equation modeling in practice: a review and recommended two-step approach. Psychological Bulletin, 103, 411-423. doi:10.1037/0033-2909.103.3.411 
Audas, R., Dobson, S., \& Goddard, J. (2002). The impact of managerial change on team performance in professional sports. Journal of Economics and Business, 54, 633-650. doi:10.1016/S0148-6195(02)00120-0

Bass, B.M. (1985). Leadership and performance beyond expectations. New York, NY: Free Press.

Bass, B.M. (1990). From transactional to transformational leadership: Learning to share the vision. Organizational Dynamics, 18, 19-31. doi:10.1016/0090-2616(90)90061-S

Bass, B.M. (1997). Does the transactional-transformational leadership paradigm transcend organizational and national boundaries? The American Psychologist, 52, 130-139. doi:10.1037/0003-066X.52.2.130

Bass, B.M. (1998). Transformational leadership: Industrial, military, and educational Impact. Mahwah, NJ: Lawrence Erlbaum Associates, Inc.

Bass, B.M., \& Avolio, B.J. (2000). Multifactor leadership questionnaires: Technical report, leader form, rater form, and scoring key for MLQ Form 5Z-Short (2nd ed.). Redwood City, CA: Mind Garden, Inc.

Bretz, R.D., Boudreau, J.W., \& Judge, T.A. (1994). Job search behavior of employed managers. Personnel Psychology, 47, 275-301. doi:10.1111/j.1744-6570.1994.tb01725.x

Burns, J.M. (1978). Leadership. New York, NY: Harper and Row.

Burton, L.J., \& Peachey, J.W. (2009). Transactional or transformational? Leadership preferences of Division III athletic administrators. Journal of Intercollegiate Sport, 2, 245-259.

Bycio, P., Hackett, R.D., \& Allen, J.S. (1995). Further assessment of Bass's (1985) conceptualization of transactional and transformational leadership. The Journal of Applied Psychology, 8, 468-478. doi:10.1037/0021-9010.80.4.468

Byrne, B.M. (2012). Structural equation modeling with mplus. New York, NY: Routeledge.

Callow, N., Smith, M., Hardy, L., Arthur, C., \& Hardy, J. (2008). Measurement of transformational leadership and its relationship with team cohesion and performance level. Journal of Applied Sport Psychology, 21, 395-412. doi:10.1080/10413200903204754

Cicero, L., Pierro, A., \& van Knippenberg, D. (2010). Leadership and uncertainty: How role ambiguity affects the relationship between leader group prototypicality and leadership effectiveness. British Journal of Management, 21, 411-421. doi:10.1111/j.14678551.2009.00648.x

Choi, J., Sagas, M., Park, S., \& Cunningham, G.B. (2007). Transformational leadership in collegiate coaching: The effects of transformational leadership on job satisfaction, organizational commitment, and organizational citizenship behavior. International Journal of Sport Management, 8, 429-445.

Cunningham, G.B. (2006). The relationships among commitment to change, coping with change, and turnover intentions. European Journal of Work and Organizational Psychology, 15, 29-45. doi:10.1080/13594320500418766

Cunningham, G.B. (2007). Perceptions as reality: The influence of actual and perceived demographic dissimilarity. Journal of Business and Psychology, 22, 79-89. doi:10.1007/ s10869-007-9052-y

Cunningham, G.B., \& Sagas, M. (2003). Occupational turnover intent among assistant coaches of women's teams: The role of organizational work experiences. Sex Roles, 49, 185-190. doi:10.1023/A:1024469132536

Cunningham, G.B., \& Sagas, M. (2004). Group diversity, occupational commitment, and occupational turnover intentions among NCAA Division IA football coaching staffs. Journal of Sport Management, 18, 236-254.

Cunningham, G.B., Sagas, M., \& Ashley, F.B. (2001). Occupational commitment and intent to leave the coaching profession. International Review for the Sociology of Sport, 36, 131-148. doi:10.1177/101269001036002001

Dalessio, A., Silverman, W.H., \& Schuck, J.R. (1986). Paths to turnover: A re-analysis and review of existing data on the Mobley, Horner, and Hollingsworth turnover model. Human Relations, 39, 245-264. doi:10.1177/001872678603900305 
Doherty, A.J. (1997). The effect of leader characteristics on the perceived transformational/ transactional leadership and impact of interuniversity athletic administrators. Journal of Sport Management, 11, 275-285.

Doherty, A.J., \& Danylchuk, K.E. (1996). Transformational and transactional leadership in interuniversity athletic management. Journal of Sport Management, 10, 292-310.

Dooley, L.M., \& Lindner, J.R. (2003). The handling of nonresponse error. Human Resource Development Quarterly, 14, 99-110. doi:10.1002/hrdq.1052

Duehr, E.E., \& Bono, J.E. (2006). Men, women, and manager: Are stereotypes finally changing? Personnel Psychology, 59, 815-846. doi:10.1111/j.1744-6570.2006.00055.x

Eagly, A.H. (1987). Sex difference in social behavior: A social-role interpretation. Hillsdale, NJ: Erlbaum.

Eagly, A.H. (1995). The science and politics of comparing women and men. The American Psychologist, 50, 145-158. doi:10.1037/0003-066X.50.3.145

Eagly, A.H. (2007). Female leadership advantage and disadvantage: Resolving the contradictions. Psychology of Women Quarterly, 31, 1-12. doi:10.1111/j.14716402.2007.00326.x

Eagly, A.H., \& Carli, L. (2003). The female leadership advantage: An evaluation of the evidence. The Leadership Quarterly, 14, 807-834. doi:10.1016/j.leaqua.2003.09.004

Eagly, A.H., Johannesen-Schmidt, M.C., \& van Engen, M.L. (2003). Transformational, transactional, and laissez-faire leadership styles: A meta-analysis comparing women and men. Psychological Bulletin, 129, 569-591. PubMed doi:10.1037/0033-2909.129.4.569

Eagly, A.H., \& Johnson, B. (1990). Gender and leadership style: a meta-analysis. Psychological Bulletin, 108, 233-256. doi:10.1037/0033-2909.108.2.233

Eagly, A.H., \& Karau, S.J. (2002). Role congruity theory of prejudice toward female leaders. Psychological Review, 109, 573-598 10.1037/0033-295X.109.3.573. PubMed doi:10.1037/0033-295X.109.3.573

Eagly, A.H., Makhijani, M.G., \& Klonsky, B.G. (1992). Gender and the evaluation of leaders: A meta-analysis. Psychological Bulletin, 111, 3-22. doi:10.1037/0033-2909.111.1.3

Eagly, A.H., Wood, W., \& Diekman, A.B. (2000). Social role theory of sex differences and similarities: A current appraisal. In T. Eckes \& H.M. Trautner (Eds.), The developmental social psychology of gender (pp. 123-174). Mahwah, NJ: Erlbaum.

Eisenberger, R., Armeli, S., Rexwinkel, B., Lynch, P.D., \& Rhoades, L. (2001). Reciprocation of Perceived Organizational Support. The Journal of Applied Psychology, 86(1), 42-51. PubMed doi:10.1037/0021-9010.86.1.42

Felps, W., Mitchel, T.R., Hekman, D.R., Lee, T.W., Holtom, B.C., \& Harman, W.S. (2009). Turnover contagion: How coworkers' job embeddedness and job search behaviors influence quitting. Academy of Management Journal, 52, 545-561. doi:10.5465/ AMJ.2009.41331075

Firth, L., Mellor, D.J., Moore, K.A., \& Loquet, C. (2004). How can managers reduce employee intention to quit? Journal of Managerial Psychology, 19, 170-187. doi:10.1108/02683940410526127

Fizel, J.L., \& D'Itri, M.P. (1996). Estimating managerial efficiency: the case of college basketball coaches. Journal of Sport Management, 10, 435-445.

Griffith, J. (2004). Relations of principal transformational leadership to school staff job satisfaction, staff turnover, and school performance. Journal of Educational Administration, 42, 333-356. doi:10.1108/09578230410534667

Grissom, J.A., Nicholson-Crotty, J., \& Keiser, L. (2012). Does my boss's gender matter? Explaining job satisfaction and employee turnover in the public sector. Journal of Public Administration: Research and Theory, 22, 649-673. doi:10.1093/jopart/ mus004

Heilman, M.W., Block, C.J., Martell, R.F., \& Simon, M.C. (1989). Has anything changes? Current characterizations of men, women, and manager. The Journal of Applied Psychology, 74, 935-942. doi:10.1037/0021-9010.74.6.935 
Higgs, M.J. (2003). Developments in leadership thinking. Leadership and Organization Development Journal, 24, 273-284. doi:10.1108/01437730310485798

Hill, G.C. (2009). The effect of frequent managerial turnover on organizational performance: A study of professional baseball managers. The Social Science Journal, 46, 557-570. doi:10.1016/j.soscij.2008.11.001

Hu, L., \& Bentler, P.M. (1998). Fit indices in covariance structure modeling: Sensitivity to underparameterized model misspecification. Psychological Methods, 3, 424-453. doi:10.1037/1082-989X.3.4.424

Judge, T.A., \& Piccolo, R.F. (2004). Transformational and transactional leadership: A metaanalytic test of their relative validity. The Journal of Applied Psychology, 89, 755-768. PubMed doi:10.1037/0021-9010.89.5.755

Kent, A., \& Chelladurai, P. (2001). Cascading transformational leadership, organizational commitment, and citizenship behavior: A case study in intercollegiate athletics. Journal of Sport Management, 15, 135-159.

Kozlowski, S.W.J., \& Ilgen, D.R. (2006). Enhancing the effectiveness of work groups and teams. Psychological Science in the Public Interest, 7, 77-124. doi:10.1111/j.15291006.2006.00030.x

Lee, T.W., \& Mowday, R.T. (1987). Voluntarily leaving an organization: An empirical investigation of Steers and Mowday's model of turnover. Academy of Management Journal, 30, 721-743. doi:10.2307/256157

Lyness, K.S., \& Judiesch, M.K. (2001). Are female managers quitters? The relationships of gender, promotions, and family leaves of absence to voluntary turnover. The Journal of Applied Psychology, 86, 1167-1178. PubMed doi:10.1037/0021-9010.86.6.1167

McPherson, B.D. (1976). Involuntary turnover and organizational effectiveness in the National Hockey League. In R.S. Gruneau \& J.G. Albinson (Eds.), Canadian sport: Sociological perspectives (pp. 259-275). Ontario: Addison-Wesley.

Meyer, J.P., Stanley, D.J., Herscovitch, L., \& Topolnytsky, L. (2002). Affective, continuance, and normative commitment to the organization: A meta-analysis of antecedents, correlates, and consequences. Journal of Vocational Behavior, 61, 20-52. doi:10.1006/jvbe.2001.1842

Mobley, W.H. (1982). Employee turnover, causes, consequences, and control. Reading, MA: Addison-Wesley.

Mobley, W.H., Griffeth, R.W., Hand, H.H., \& Meglino, B.M. (1979). Review and conceptual analysis of the employee turnover process. Psychological Bulletin, 86, 493-522. doi:10.1037/0033-2909.86.3.493

Moynihan, D.P., \& Landuyt, N. (2008). Explaining turnover intention in state government: Examining the roles of gender, life cycle, and loyalty. Review of Public Personnel Administration, 28, 120-135. doi:10.1177/0734371X08315771

Mowday, R.T., Koberg, C.S., \& McArthur, A.W. (1984). The psychology of the withdrawal process: A cross-validation test of Mobley's intermediate linkages model of turnover in two samples. Academy of Management Journal, 27, 79-94. PubMed doi: $10.2307 / 255958$

Organ, D. W., \& Ryan, K. (1995). A meta-analytic review of attitudinal and dispositional predictors of organizational citizenship behavior. Personnel Psychology, 48(4), 775802. doi:10.1111/j.1744-6570.1995.tb01781.x

Polychroniou, P. (2009). Relationship between emotional intelligence and transformational leadership of supervisors: The impact on team effectiveness. Team Performance Management, 15, 343-356. doi:10.1108/13527590911002122

Powell, G.N., Butterfield, D.A., \& Bartol, K.M. (2008). Leader evaluations: A new female advantage? Gender in Management: An International Journal, 23, 156-174. doi:10.1108/17542410810866926

Riger, S. (1993). What's wrong with empowerment. American Journal of Community Psychology, 21, 279-292. doi:10.1007/BF00941504

Rosser, V.J., \& Townsend, B.K. (2006). Determining public 2-year college faculty's intent to leave: An empirical model. The Journal of Higher Education, 77, 124-147. doi:10.1353/ jhe. 2006.0006 
Rowold, J. (2006). Transformational and transactional leadership in martial arts. Journal of Applied Sport Psychology, 18(4), 312-325. doi: 10.1080/10413200600944082

Sagas, M., \& Ashley, F. (2001). Gender differences in the intent to leave coaching: The role of personal, external, and work-related variables. International Journal of Sport Management, 2, 297-314.

Sagas, M., Cunningham, G.B., \& Pastore, D.L. (2006). Predicting head coaching intentions of male and female assistant coaches: An application of the theory of planned behavior. Sex Roles, 54, 695-705. doi:10.1007/s11199-006-9035-x

Salomo, S., \& Teichmann, K. (2000). The relationship of performance and managerial succession in the German premier football league. European Journal for Sport Management, 7, 99-119.

Shaw, S., \& Frisby, W. (2006). Can gender equity be more equitable? Promoting and alternative frame for sport management research, education, and practice. Journal of Sport Management, 20, 483-509.

Shaw, J.D., Gupta, N., \& Delery, J.E. (2005). Voluntary turnover and organizational performance. Academy of Management Journal, 48, 50-68. doi:10.5465/AMJ.2005.15993112

Sicherman, N. (1996). Gender differences in departures from a large firm. Industrial \& Labor Relations Review, 49, 484-505. doi:10.2307/2524199

Son, J., Joshi, A., \& Roh, H. (2012). Proceedings from AOM '12: The contingent effects of gender on performance and turnover: A meta-analytic review. Boston, MA: Pace.

Stroh, L.K., Brett, J.M., \& Reilly, A.H. (1996). Family structure, glass ceiling, and traditional explanations for the differential rate of turnover of female and male managers. Journal of Vocational Behavior, 49, 99-118. doi:10.1006/jvbe.1996.0036

Tse, H.H.M., \& Lam, W. (2008). Transformational leadership and turnover: The roles of LMX and organizational commitment. Academy of Management Proceedings.

Vallee, C.N., \& Bloom, G.A. (2005). Building a successful university program: Key and common elements of expert coaches. Journal of Applied Sport Psychology, 17, 179-196. doi:10.1080/10413200591010021

Wang, Y.S., \& Huang, T.C. (2009). The relationship of transformational leadership with group cohesiveness and emotional intelligence. Social Behavior and Personality, 37, 379-392 10.2224/sbp.2009.37.3.379. doi:10.2224/sbp.2009.37.3.379

Watrous, K.M., Huffman, A.H., \& Pritchard, R.D. (2006). When coworkers and managers quit: The effects of turnover and shared values on performance. Journal of Business and Psychology, 21, 103-126. doi:10.1007/s10869-005-9021-2

Weisberg, J., \& Kirschenbaum, A. (1993). Gender and turnover: A re-examination of the impact of sex on intent and actual job changes. Human Relations, 46, 987-1006. doi:10.1177/001872679304600805

Wells, J.E., \& Welty Peachey, J. (2011). Turnover intentions: Do leadership behaviors and satisfaction with the leader matter? Team Performance Management, 17, 22-43. doi:10.1108/13527591111114693

Welty Peachey, J., \& Burton, L. (2011). Male or female athletic director? Exploring perceptions of leader effectiveness and a (potential) female leadership advantage with intercollegiate athletic directors. Sex Roles, 64, 416-425. doi:10.1007/s11199-010-9915-y

Welty Peachey, J., \& Burton, L. (2012). Transactional or transformational leaders in intercollegiate athletics? Examining the influence of leader gender and subordinate gender on evaluation of leaders during organizational culture change. International Journal of Sport Management, 13, 1-28.

White, P., Persad, S., \& Gee, C.J. (2007). The effect of mid-season coach turnover on team performance: The case of the National Hockey League (1989-2003). International Journal of Sports Science \& Coaching, 2, 143-152. doi:10.1260/174795407781394275

Yukl, G.A. (1989). Leadership in organizations (2nd ed.). Englewood Cliffs, NJ: Prentice Hall.

Yukl, G.A. (2006). Leadership in organizations (6th ed.). Upper Saddle River, NJ: Prentice Hall. 